\title{
CHOLINESTERASE AND GLUTATHIONE S-TRANSFERASE IN THE EARTHWORM APPORECTODEA CALIGINOSA AS BIOMARKERS OF ORGANOPHOSPHATE EXPOSURE
}

\author{
L.H. BOOTH, V. HEPPELTHWAITE \\ and C.T. EASON \\ Landcare Research, P.O. Box 69, Lincoln, New Zealand
}

\begin{abstract}
Two potential biomarkers of pesticide contamination were investigated in Apporectodea caliginosa. Juvenile earthworms were exposed to sub-lethal concentrations of the organophosphates chlorpyrifos and diazinon to assess their effect on cholinesterase and glutathione S-trasferase activities. Cholinesterase which is inhibited by organophosphates, was inhibited by $72 \%$ by diazinon $(\mathrm{P}<0.001)$ and $87 \%$ by chlorpyrifos $(\mathrm{P}<0.001)$ within 1 day of exposure and remained depressed 14 days after exposure. Glutathione S-transferase (GST) is induced by xenobiotics compared to controls and diazinon induced GST by $56 \%$ after 14 days $(\mathrm{P}<0.001)$ and chlorpyrifos induced GST by $148 \%$ after 14 days exposure $(\mathrm{P}<0.005)$.
\end{abstract}

Keywords: earthworm, cholinesterase, glutathione S-transferase, biomarker, invertebrates.

\section{INTRODUCTION}

There is concern that the widespread use of pesticides and other agrochemicals may be damaging agro-ecosystems and wildlife resources throughout New Zealand. Enzyme assays in the common earthworm Apporectodea caliginosa (Savigny) are being developed to give a measure of pesticide exposure and as biomarkers of toxicity.

Organophosphate and carbamate pesticides act by inhibiting cholinesterases (ChE) which are a group of enzymes in the central nervous system. Edwards and Fisher (1991) have shown that cholinesterase (ChE) activity in several terrestrial and aquatic invertebrates can be significantly inhibited in cases of sub-lethal exposures to pesticides, and they suggest that this enzyme may be a sensitive biomarker with which to assess environmental contamination by such pesticides.

Glutathione S-transferase (GST) is involved in the detoxification of various xenobiotic chemicals. In insects, GST plays an important role in the biotransformation of various insecticides (Lamoureux and Rusness 1987; Motoyama 1980), including the degradation of some organophosphorus compounds (Yang 1976). Therefore, this enzyme could be useful as an indicator of pesticide exposure. However, few specific data are available on the sub-lethal effects of pesticides on GST activity in non-target species such as earthworms.

The objective of this research was to determine the effects of chlorpyrifos and diazinon at sub-lethal doses on ChE and GST activities in the common earthworm A. caliginosa.

\section{Pesticides}

\section{MATERIALS AND METHOD}

The pesticides tested in these experiments were the organophosphates diazinon (Basudin 600EW; Ciba-Geigy NZ Ltd, Avondale, NZ) and chlorpyrifos (Lorsban 40EC; DowElanco (NZ) Ltd, New Plymouth, NZ). Both of these pesticides are commonly used on pastures in the Canterbury region of New Zealand, mainly for control of grass grub and porina caterpillars. 


\section{Determination of lethal and sub-lethal pesticide concentrations}

Pesticide was mixed into soil as an aqueous solution to give the desired working concentration. Control soil contained water and no pesticide. Five hundred grams of the prepared soil was placed into $500 \mathrm{ml}$ glass jars and 10 juvenile (1-3 months) laboratory reared $A$. caliginosa were added to quadruplicate jars at the following concentrations - diazinon $60,70,90,100,120 \mathrm{mg} / \mathrm{kg}$ and chlorpyrifos $28,36,44,60$, $76 \mathrm{mg} / \mathrm{kg}$. The jars were maintained at $20^{\circ} \mathrm{C}$ (optimal temperature for growth) and constant light. Mortality was assessed after 14 days.

\section{Assessment of enzyme activity after sub-lethal pesticide exposure}

Earthworms were exposed to a dose estimated from the initial bioassay as the highest sub-lethal dose of diazinon $(60 \mathrm{mg} / \mathrm{kg})$ or chlorpyrifos $(28 \mathrm{mg} / \mathrm{kg})$. Soil was prepared as above and $100 \mathrm{~g}$ placed into each of five replicate $100 \mathrm{ml}$ jars for each pesticide for each time point (see below). Four juvenile $A$. caliginosa were added to each of the jars, which were maintained at $20^{\circ} \mathrm{C}$ and constant light. At 1, 2, 4, 7 and 14 days, two earthworms were removed from the replicate jars from each timepoint and frozen at $-20^{\circ} \mathrm{C}$ for subsequent $\mathrm{ChE}$ activity analysis. The remaining two earthworms were frozen for subsequent GST activity analysis. The enzyme activity for the two earthworms was averaged to give a "replicate" activity.

\section{Enzyme biomarker assays}

Frozen samples of earthworms were defrosted on ice. The samples for determination of ChE activity were homogenised in phosphate buffer (0.02M; $\mathrm{pH} 7.5)$. Samples were maintained on ice for 60 minutes and the crude homogenate was used for analysis. For GST activity, earthworm samples were homogenised in phosphate buffer, pH 7.0. Analysis was conducted using the supernatant following centrifugation of the homogenate at $15,000 \mathrm{rpm}$ for 5 minutes.

The method for the determination of ChE activity was adapted from Ellman et al. (1961), for use in worms and minimised for microtitre plates. The substrate acetylthiocholine iodide was added to the reaction mixture containing the homogenate and 5,5',-Dithio-bis-2-nitrobenzoic acid (DTNB). Activity was expressed as nmol acetylthiocholine hydrolysed $/ \mathrm{min} / \mathrm{mg}$ protein.

The method for the determination of GST activity was adapted from Habig et al. (1974), for earthworms and minimised for microtitre plates. The substrate 1-chloro2,4-dinitrobenzene (CDNB) was added to the reaction mixture containing glutathione (GSH) and homogenate. Activity was expressed as nmol GSH conjugated $/ \mathrm{min} / \mathrm{mg}$ protein.

Samples were analysed for total protein content using the Bradford method (Bradford 1976). Bovine serum albumin was used as a standard.

\section{Statistical analysis}

Mortality data was analysed by probit analysis (Finney 1971) to calculate the $\mathrm{LC}_{50}$ (the concentration of pesticide which kills $50 \%$ of the sample population). Results were analysed by two-way ANOVA with a Tukey's test to determine differences between treatments and time points.

\section{Toxicity experiments}

\section{RESULTS}

After 14 days, the $\mathrm{LC}_{50}$ was $102 \mathrm{mg} / \mathrm{kg}$ and $69 \mathrm{mg} / \mathrm{kg}$ for diazinon and chlorpyrifos, respectively. Non-lethal concentrations were $60 \mathrm{mg} / \mathrm{kg}$ and $28 \mathrm{mg} / \mathrm{kg}$ for diazinon and chlorpyrifos, respectively. These sub-lethal doses are 5 and 7 times higher than the normal application rate for diazinon and chlorpyrifos respectively.

\section{Analysis of enzyme activities}

Worms exposed to $60 \mathrm{mg} / \mathrm{kg}$ diazinon showed $72 \%$ inhibition of $\mathrm{ChE}$ within 24 hours compared with control worms $(\mathrm{P}<0.005)$ and $28 \mathrm{mg} / \mathrm{kg}$ chlorpyrifos inhibited ChE activity by $87 \%$ compared with control activity $(\mathrm{P}<0.001)$. This activity did not return to control levels over the 14-day exposure period for either pesticide $(\mathrm{P}<0.001)$. Control activity was constant throughout the duration of the experiment (Figure 1a).

GST activity was significantly induced by diazinon after 7 days $(\mathrm{P}<0.001)$ and showed a maximum induction of $56 \%$ compared with controls after 14 days. GST 
activity was significantly induced by chlorpyrifos $(\mathrm{P}<0.005)$ to $148 \%$ of control activity, but this induction was only evident after 14 days. Control activity was constant over the 14-day experiment (Figure 1b).

a)

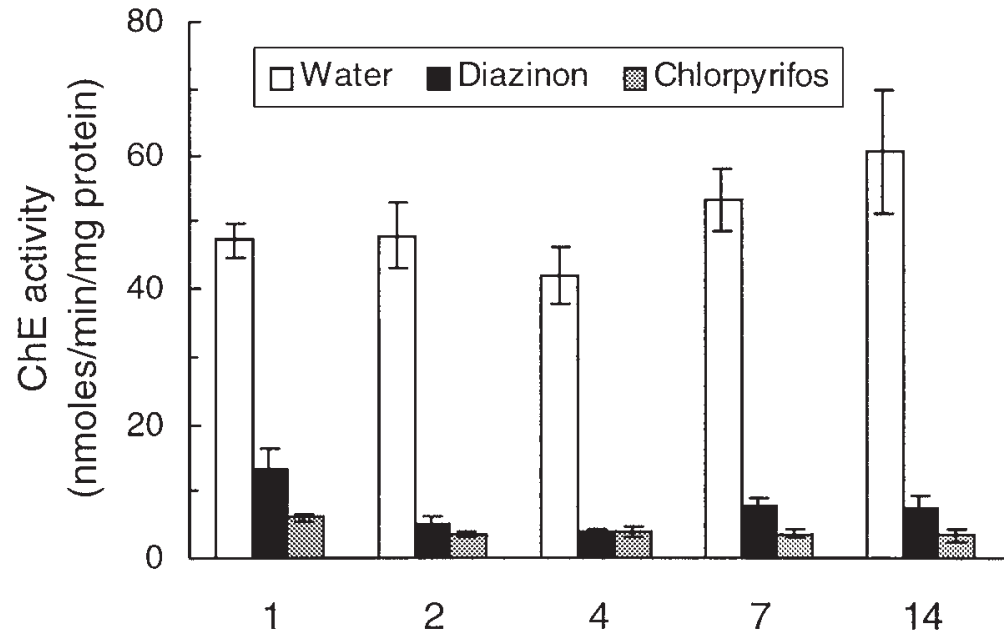

b) Exposure time (days)

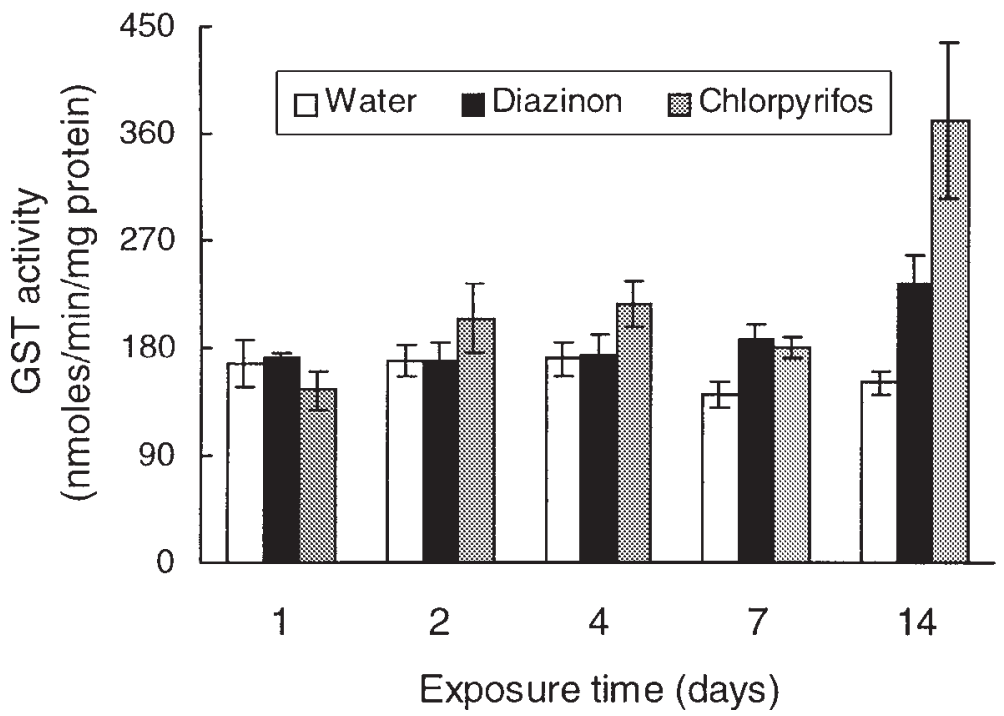

FIGURE 1: a) ChE and b) GST activity in $A$. caliginosa exposed to sublethal doses of diazinon. Values are mean activity \pm standard error $(n=5)$. 


\section{DISCUSSION}

Two potential biomarkers of pesticide contamination were investigated in a common earthworm species following exposure to two widely used insecticides. A. caliginosa was chosen as an indicator species in New Zealand because of its widespread occurrence in arable and pasture lands and its consequent vulnerability to surface applied pesticides, making it an ideal candidate for assessment of agroecosystem contamination.

Cholinesterase activity is routinely used in vertebrate animals to diagnose exposure to organophosphates (Fairbrother et al. 1991; Edwards and Fisher 1991). Acetylcholinesterase (AChE) activity has been shown to be strongly inhibited by organophosphates and carbamates in a number of invertebrate species (Day and Scott 1990). However, the potential use of this measurement in earthworms to indicate impacts of pesticides has not been well recognised. Kale and Krishnamoorthy (1982) showed up to $80 \%$ inhibition of ChE by carbaryl in the earthworm Pontoscolex corethrurus. Stenersen (1979) exposed earthworms to a number of organophosphates and carbamates by dipping them in an aqueous solution and demonstrated up to $85 \%$ inhibition of AChE levels, compared to controls. In the present study, the activity of $\mathrm{ChE}$ in earthworms was severely inhibited by diazinon and chlorpyrifos within 24 hours of exposure to sub-lethal levels of pesticides and this activity showed no return to pre-exposure levels even after 14 days.

GST activity was induced by both chlorpyrifos and diazinon and this is consistent with reports of induction of GST activity in worms by other pesticides (Hans et al. 1993 ) which showed a maximum induction of $250 \%$ by endosulphan.

These results show that ChE and GST have potential as biomarkers of short-term pesticide exposure. Due to its slower response rate (14 days compared with 1-day exposure), GST may be a useful marker of long-term exposure whereas ChE may be more indicative of acute exposures. Further experiments are required to determine the duration of enzyme alterations following termination of exposure. If activity returns to pre-exposure levels fairly quickly, ChE and GST activity may be useful only as short-term indicators. If ChE activity remains depressed and GST activity induced for a significant length of time, they may serve as tools when establishing the cause and effect in deteriorating agro-ecosystems. Once this is established, the next stage is to link the observed changes in enzyme activity with effects on earthworm populations, reproduction and survival.

Ultimately, these biomarkers will be developed for use in a field situation, i.e., for comparison of enzyme activities in earthworms from a contaminated area with earthworms from an organic control area. In order to apply these biomarkers in the field, further research is currently being conducted on the effects of environmental factors (e.g., temperature, soil type and soil $\mathrm{pH}$ ) on these enzyme activities. The usefulness of these biomarkers will also be compared with other earthworm biomarkers, such as the lysosomal neutral red assay which has proved useful for detecting heavy metal contamination (Svendsen and Weeks 1997a and b), and may also be sensitive to other classes of xenobiotic.

\section{ACKNOWLEDGEMENTS}

The authors acknowledge the Foundation for Research Science and Technology CO9614 for funding this research, and thank Dr Kathryn O'Halloran, Dr Jason Weeks, and Dr Jorgen Stenersen for advice and editorial comments.

\section{REFERENCES}

Bradford, M.M., 1976. A rapid and sensitive method for the quantitation of microgram quantities of protein utilizing the principle of protein-dye binding.Anal. Biochem. 72: $248-254$.

Day, K.E. and Scott, I.M., 1990. Use of acetylcholinesterase activity to detect sublethal toxicity in stream invertebrates exposed to low concentrations of organophosphate insecticides. Aquatic Toxicol. 18: 101-114. 
Edwards, C.A. and Fisher, S.W., 1991. The use of cholinesterase measurements in assessing the impacts of pesticides on terrestrial and aquatic invertebrates. Pp 256275 In: Cholinesterase-inhibiting Insecticides: their Impact on Wildlife and the Environment, P. Mineau (Ed); Elsevier, Amsterdam.

Ellman, G.L., Courtenay, K.D., Valentino, A.J. and Featherstone, E.M., 1961. A new rapid colorimetric determination of acetylcholinesterase activity. Biochem. Pharmacol. 7: 88-95.

Fairbrother, A., Marden, B.T., Bennett, J.K. and Hooperds, M.J., 1991. Methods used in determination of cholinesterase activity. Pp 35-72 In: Cholinesterase-inhibiting Insecticides: their Impact on Wildlife and the Environment, P. Mineau (Ed), Elsevier, Amsterdam.

Finney, D.J., 1971. Probit analysis. 3rd edition. University Printing House, Cambridge.

Habig, W.H., Pabst, M.J. and Jacoby, W.B., 1974. GlutathioneS-transferases, the first enzymatic step in mercapturic acid formation. J. Biol. Chem. 249(22): 321-336.

Hans, R.K., Khan, M.A., Farooq, M. and Beg, M.U., 1993. Glutathione-S-transferase activity in an earthworm (Pheretima posthuma) exposed to three insecticides. Soil Biol. and Biochem. 25(4): 509-511.

Kale, R.D. and Krishnamoorthy, R.V., 1982. Residual effect of Sevin ${ }^{\circledR}$ on the acetyl cholinesterase activity of the nervous system of earthwormPontoscolexcorethrurus. Curr. Sci. 51(18): 885-886.

Lamoureux, G.L. and Rusness, D.G., 1987. Synergism of diazinon toxicity and inhibition of diazinon metabolism in the house fly by Tridiphane: inhibition of glutathione-S-transferase activity. Pest. Biochem. Phys. 27: 318-329.

Motoyama, N., 1980. Glutathione-S-transferases: Their role in the metabolism of organophosphorus insecticides. Rev. Biochem. Toxicol. 2: 49-69.

Stenersen, J., 1979. Action of pesticides on earthworms. Part 3: Inhibition and reactivation of cholinesterases in Eisenia foetida (Savigny) after treatment with cholinesterase-inhibiting insecticides. Pest. Sci.10: 113-122.

Svendsen, C. and Weeks, J.M., 1997a. Relevance and applicability of a simple earthworm biomarker of copper exposure: I. Links to ecological effects in a laboratory study with Eisenia andrei. Ecotox. Environ. Safety 36: 72-79.

Svendsen, C. and Weeks, J.M., 1997b. Relevance and applicability of a simple earthworm biomarker of copper exposure: II. Validation and applicability under field conditions in a mesocosm experiment with Lumbricus rubellus. Ecotox. Environ. Safety 36: 80-88.

Yang, R.S.H., 1976. Enzyme conjugation and insecticide metabolism. Pp 177-187In: Biochemistry and Physiology of Insecticides, C.F. Wilkinson (Ed); Plenum Press, New York. 